\title{
CLASSIC LEGACIES FROM A DISASTROUS BATTLE
}

\section{REDMOND MCLAUGHLIN}

Shortly after the Indian Mutiny, a war of more than ordinary fatuity led to the opening of a great window of humanitarian hope. In 1859 fighting broke out between two imperial but incompetent leaders, the Emperors Franz Josef of Austrita and Napoleon III. The latter, though Bonaparte's nephew, lacked any spark of military genius. After the disaster at Solferino in Northern Italy he made the feeble comment that he had had enough of war: 'Le hazard joue un trop grand rôle'. His incompetent opponent felt even less like making any more efforts to establish himself as a worthy commander in battle.

These mediocrities blundered into a collision of huge forces-with 138,000 French and Piedmontese against 129,000 Austrians. Nearly 40,000 men were killed or wounded. But a day of useless carnage set in motion a great forward surge of civilisation.

The pathetic young Emperor of Austria wrote to his beloved 'Sisi'-the Empress Elizabeth: 'I spent a dreadful evening: the place was a confusion of wounded refugees, waggons and horses. That is the sad history of a dreadful day ... I have learnt and experienced much and I know what it feels like to be a beaten General' (His final lesson in defeat came 55 years later at the hands of the Serbians at the start of the First World War).

But, defeated emperors apart, the battle produced some of the most scarifying scenes of horror, with nearly as many casualties as at Waterloo, and far less provision for their care. Nor were there any gifted men in the background to rally to the help of the overwhelmed army surgeons-unlike 1815 no Bells, no Guthries, only young Baron Larrey, the great man's son. However, he had no equivalent authority even as Surgeon-in-Chief, and "was compelled to stand a helpless spectator of the carnage'.

There was at Solferino on that disastrous Midsummer Day in 1859, one man whose aptitude for spectatorship would far outstrip the younger Larrey's. His presence was purely fortuitous-'a mere tourist', as he called himself. His name was Jean Henri Dunant, and his profession of banking was linked with a passion for history. Already at 31 he had completed two books. He had not, one gathers, the slightest interest in clinical matters as such. But he greatly wished to meet Napoleon III, and to ensure his patronage for a business project in Algeria. He was hoping to flatter the French Emperor with his book bearing the portentous title 'The Empire of Charlemagne Restored, or the Holy Roman Empire Renewed by his Majesty the Emperor Napoleon III'. Dunant was to prove an admirable optimist, but he was certainly naïve.

The war seemed his cue to meet the Emperor. He left for Italy in his best tropical suit. A friend, General de Beaufort, gave him the necessary written introduction. On the day of the 'battle, which he never claimed to have viewed, Dunant found himself in the village of Castiglione which until early morning had been Napoleon's headquarters. 
At once he was engulfed in a flood of wounded. There was everywhere a serious shortage of stretchers and ambulances. Medical stores were piled high in the docks at Genoa, plentiful but useless. The few surgeons were overwhelmed. There was water and food at hand, but men still died of hunger and thirst.

Dunant, entirely unacquainted with actual war-or surgery-"had the rare privilege of being able to help at these moving scenes'. He writes of his recollections being just general impressions. He describes the field of battle completely covered with men and horses, and the pitiful debris of war-helmets, weapons, knapsacks, and so forth. The most severely wounded, with their expressions of extreme lassitude, did not seem to understand what was said to them: 'They followed you with haggard eyes'. Those with a calm appearance, he realized, were men instantly killed. Others he saw in the posture of a final agony. $\mathrm{He}$ spent three days and three nights, covering the bodies as they lay on the battlefield. A plan to move the wounded to the town of Brescia, twenty miles away, failed; the Austrians had in defeat removed nearly every farm cart or similar conveyance, under forced requisition. There was nothing for it, but to hold the wounded under primitive conditions for two or three days, so the congestion at Castiglione was indescribable.

The aspect of the catastrophe that most deeply affected Dunant was the sheer shortage of manpower to dole out the water and food that was readily available. There was also an abundance of dressings, but often no one to apply them. Most of the doctors had moved off to another town; there were almost no nursing orderlies. So, for better or worse, the organisation of a voluntary service was essential-a terribly hard task amidst such confusion. The air was filled with the stench of corruption and death. Fresh convoys of wounded continued to converge on the little town.

The wonder is that this young businessman stuck it out, with almost no support from any medical team, trying to communicate with men so mutilated that they could only use their hands in a pitiful pantomime, and make gutteral noises. The wounded exhibited great mistrust towards any helpers of the opposite army or nation.

However, the local women followed Dunant's example by showing the same kindness to all in need-all equally unfamiliar. 'Tutti fratelli' was their reiterated response - they were all brothers. 'I pay homage' wrote Dunant, 'to these compassionate women and young girls'. Nothing deterred these gallant helpersnot even the butchery all around them.

At last, on the afternoon of the 27th of June, exhausted and sleepless, he found his own carriage-a stroke of luck-and left the scene. He could once more, as he put it, 'savour the freshness of the evening air'.

Six days after the battle he went to Brescia. The town had been transformed, not with a huge casualty station, like Castiglione, but as it were into one immense hospital. The two cathedrals, the churches, the palaces, the convents, the colleges, the barracks-every building was occupied with the victims of Solferino. 
But the nightmare of the battered M. Dunant was still incomplete, for he now viewed an amputation without chloroform, carried out by a single surgeon with a totally incompetent assistant. In a near-by hospital chloroform was available. Dunant realized that deaths from chloroform were not rare; and he shared the misery of hoping in vain to see signs of life in a man who, moments before, had been talking to him.

In his classic book Un Souvenir de Solférino, which has failed during over a century to appear in an English translation, he asks, "Why have I told of all these scenes of pain and desolation?' Had he seemed complacent?

He submits the right to pose another question: 'Should there not be a way of founding voluntary societies with the aim of giving . . . succour to the wounded in wartime?' He closes by stating that through his first edition (1862) this appeal has been widely heard, and well-received by people of all ranks, civil and military.

'The name of Miss Nightingale, so universally known since the Crimean War, leads us to reproduce some words addressed on her behalf concerning the subject of this book: Claydon, Bucks. 14 January 1863-Miss Nightingale read attentively and with great interest the horrible account of the battles written by M. H. Dunant; she says it is only too faithfully a representation. She entertains no doubt with regard to Monsieur Dunant's proposal ...'

On other occasions Miss Nightingale was apt to be somewhat more abrasive, as we shall see.

The hero of this unlikely epic was born in Geneva in 1828 with affluent surroundings. As a child of six he showed a depth of social conscience which must have seemed almost morbid. He saw and heard some Swiss convicts at work. The sight of them breaking stones and the clank of their shackles stunned him, and remained with him to the end of his life.

His prosperous background gave him ample scope for travel, and for charitable activities. He entirely lacked any kind of medical background. By an unhappy aberration, a popular biographer of Miss Nightingale has turned Dunant positively into a young physician. This makes nonsense of the impact he was about to make on the leaders of his time, in the first instance by his remarkable book. For it was his layman's reaction that made so deep an impression-just as it was Miss Nightingale's womanhood which primarily stirred her contemporaries.

Shattered by his experience at Solferino, he went to recuperate in the High Alps. Here he had what his biographer described as 'an apocalyptic vision'. As he put it, in writing $A$ Memory of Solferino, 'I was, as it were, lifted out of myself, compelled by some higher power and inspired by the breath of God'. He writes of 'an intuition, vague and yet profound, that my work was an instrument of His Will ... The poignant and grevious experiences at Solferino had to be told ... .I was overcome with compassion, horror and pity'.

But it was his practical suggestions that counted most powerfully: 'Would it 
not be desirable . . . to formulate some international principle, sanctioned by a convention inviolate in character? . . Humanity and civilisation call imperiously for such an organisation'.

In developing his aspirations, Dunant was greatly helped by Gustave Moynier, a brilliant advocate of 36 , working also in Geneva. It was his initiative and practical wisdom that made good what the vague and politically inept Dunant had dreamed of. The initial public discussion in Geneva early in 1863 was dominated by Moynier. Later a new and important figure was co-opted, General Dufour. He was a soldier, a Swiss born in 1787, who had fought under Napoleon I. Later he had taken a leading part in the short Swiss civil war of 1847, in which his humane attitudes had been noted and admired. Now he was appointed Chairman of the vital International Conference at Geneva in September 1863. Dufour, who had had a role in evolving the Swiss Federal flag more than 30 years before, was now able to reverse the colours to become, as a symbol of compassion, a red cross on a white ground.

There were 36 delegates from 14 countries. The outlines were broad and flexible-and proved able to stand the hard pressures of the century ahead. Dunant did not address the Conference, but was accorded what is now called a standing ovation. This conference led swiftly to the rightly famous Geneva Convention of 1864. Dufour proved an admirable chairman and leader. Nine short articles to define the Convention were agreed; these were mainly concerned with protection for hospitals and for non-combatant helpers, as well as the 'neutralization' of men severely wounded. There must be no suspicion of espionage by these volunteers.

Unhappily Miss Nightingale was less generous to activities which, as Dunant had often affirmed, stemmed from the inspiration of her work in the Crimea. She wrote a sour letter to Surgeon-General Longmore, Great Britain's chief delegate. In this she said, in her sarcastic vein, that it will be quite harmless for our Government to sign the Convention as it now stands. It amounts to nothing more that the declaration that humanity to the wounded is a good thing'. She was reminded of an operatic chorus, with the leading Europeans singing, 'We will never be cruel more' . . . 'The Convention will not keep the barbarous nations like [Tsarist] Russia from being inhumane'. (Some who suffered and died in Japanese labour camps might have felt she had a point.) Yet one can see why some observers viewed her less as a Lady with a Lamp than as a tigress robbed of her dinner.

Sad to say, Dunant subsided like his critic into chronic hypochondria at quite an early age. For those of us who were not at Solferino or Scutari, it would be arrogant to feel superior. Dunant himself suffered a worse fate thán her long years on the sofa at South Street in London; his financial speculations were so unwise that he lost all of his own money, and most of his family's. At 39 he left his native Geneva for ever, living miserably for a while in Paris, subsisting on the gifts of admirers, a victim of grandiose dreams. By the mid 1880s he was a permanent invalid, though not yet 50, living in a hospital at 
Heiden. In 1901 he was awarded the Nobel Peace Prize. He died like Miss Nightingale in 1910.

His monument is an International Treaty which (excluding certain Far Eastern countries) has been honoured by most, though not all, warring nations. It has also been so comprehensive that only three revisions have been needed in a century. As has been most justly written: 'Humanity and many millions of fighting men, who had 'never even heard of his name, owe to Dunant an imperishable debt. This is his memorial'.

A rare footnote from half a century later may illustrate the measureless scope of his 'memorial'. Captain Eric Bush, D.S.O., D.S.C., R.N. in his highly personal book 'Gallipoli', records this stiring episode. In May 1915 a small British raiding party came to grief in the dawn, and had to be withdrawn.

"They had suffered four killed and sixteen wounded. All the wounded were successfully re-embarked, except for one who could not be found. The dead were left where they fell.

Later in the day the lost wounded man was seen to be crawling on hands and knees towards the water's edge. The Dartmouth sent in her steamboat, with a dinghy from the Chelmer, both boats wearing Red Cross flags. The Turks did not object; on the contrary they helped the wounded man and, whilst waiting for the rescue party to land, bound up his wounds under their own Red Crescent flag.

After this casualty had been collected, some more enemy soldiers appeared from behind the scrub. Under the eyes of the Fleet they buried our dead; and when the job was over they fell into line facing the sea and solemnly presented arms."

Perhaps the ghost of Henri Dunant witnessed this small part of his legacy.

Annual Prizes

Montefiore Memorial 1977-Major P. Parkes Memorial-Colonel D. E.

F. T. Sewell

Alexander Memorial-Major C. M. Bate

Leishman Memorial-Major K. B. Hughes

Worsley

North Persian Forces MemorialMajor G. W. Brown

The Consultants-Colonel J. McEwan 